\title{
Genetikai tényezők a hypopituitarismus kialakulásában. A transzkripciós faktorok szerepe az agyalapimirigy-elégtelenség hátterében
}

\author{
Tőke Judit dr. ${ }^{1}$ - Bertalan Rita dr. ${ }^{3}$ - Gergics Péter dr. ${ }^{4}$ - Halász Zita dr. ${ }^{2}$ \\ Semmelweis Egyetem, Általános Orvostudományi Kar, ${ }^{1}$ II. Belgyógyászati Klinika, \\ ${ }^{2}$ I. Gyermekgyógyászati Klinika, Budapest \\ ${ }^{3}$ Csolnoky Ferenc Kórház, Veszprém \\ ${ }^{4}$ Department of Human Genetics, University of Michigan, Ann Arbor, MI, USA
}

\begin{abstract}
A hypothalamohypophysealis rendszer fejlődési rendellenességei klinikai megjelenésükben sokszínú hypophysiselégtelenséggel járhatnak. Ezen fejlődési rendellenességek jelentős részét a hypophysis organogenezisét szabályozó transzkripciós faktorok genetikai hibái okozhatják. Az agyalapi mirigy fejlődésének korai szakaszában expresszálódó transzkripciós faktorokat kódoló gének mutációi olyan összetett fejlődési rendellenességekhez vezethetnek, amelyekben a hypopituitarismushoz egyéb központi idegrendszeri malformációk is társulnak. Az organogenezis későbbi szakaszát szabályozó transzkripciós faktorok genetikai eltérései jellemzően többszörös, ritkán izolált agyalapi mirigy hormonhiányt okoznak extrahypophysealis manifesztáció nélkül. A hypophysistranszkripciós faktorok genetikai defektusainak azonosítása segítséget adhat a hormonhiányok előrejelzésében és az érintett családtagok szürésében. Egyes hypophysistranszkripciós faktorok expressziója felnőttkorban is kimutatható, aminek fontos klinikai jelentősége van a hypophysisadenomák WHO által ajánlott új rendszerü, ezen faktorok expresszióját is figyelembe vevő osztályozásában.
\end{abstract}

Orv Hetil. 2018; 159(7): 278-284.

Kulcsszavak: veleszületett hypopituitarismus, hypophysistranszkripciós faktorok, hypophysisadenoma

\section{Genetic factors in hypopituitarism. The role of transcription factors in pituitary hormone deficiency}

Developmental disorders affecting the hypothalamic-pituitary system can result in pituitary hormone deficiency showing a diverse clinical presentation. A significant majority of these disorders are closely linked to defects in transcription factor genes which play a major role in pituitary development. Those affecting the early phase of organogenesis typically lead to complex conditions affecting the pituitary as well as structures in the central nervous system. Transcription factors involved in the late phase can result in combined but rarely isolated pituitary hormone deficiency without extra-pituitary manifestation. Identifying the defects in these pituitary transcription factor genes may provide a useful tool in predicting disease progression as well as screening family members. Several pituitary transcription factors can be detected in the adult gland as well which is strongly emphasized in the World Health Organization's most recent guideline for pituitary tumor classification. Our review summarizes the current essential knowledge relevant for clinical endocrinologists.

Keywords: congenital hypopituitarism, pituitary transcription factors, pituitary adenoma

Töke J, Bertalan R, Gergics P, Halász Z. [Genetic causes of hypopituitarism. Clinical significance of pituitary transcription factors]. Orv Hetil. 2018; 159(7): 278-284.

(Beérkezett: 2017. december 21.; elfogadva: 2018. január 11.) 


\section{Rövidítések}

ACTH = adrenokortikotrop hormon; DAXI = a DSS-AHC kritikus régiója az X-kromoszómán, l-es gén (NR0B1); E2 = ösztradiol; ER $\alpha=$ ösztrogénreceptor $2, \mathrm{FGFl}=$ fibroblastnövekedési faktor-1; FSH = folliculusstimuláló hormon; GATA2 = GATA-kötő fehérje-2; GH = növekedési hormon; IGSF1 = immunoglobulin superfamily, member 1 , glikoprotein; LH = luteinizáló hormon; PC2 = prohormonkonvertáz- 2 ; POUlF1 $(\mathrm{PIT} 1)=$ POU domain, class 1, transzkripciós faktor- $1 ; \mathrm{PRL}=$ prolaktin; $\mathrm{PROPl}=$ prophet of Pitl transzkripciós faktor; $\mathrm{SFl}$ = szteroidogenetikus faktor- $1(\mathrm{NR} 5 \mathrm{Al}) ; \mathrm{TBLlX}=$ transducin (beta)-like IX-linked protein; T-Pit = T-box factor, pituitary, transzkripciós faktor $(\mathrm{TBX19})$; TSH = pajzsmirigy-stimuláló hormon

Az izolált növekedésihormon-hiánnyal vagy kombinált hormonhiánnyal járó veleszületett hypophysiselégtelenség incidenciája kb. 1:8000. Az esetek többsége sporadikus megjelenésü, azonban mintegy 5-30\%-ban a betegség családi halmozódást mutat $[1,2]$.

Veleszületett hypophysiselégtelenséggel sok esetben a hypothalamohypophysealis rendszer, valamint egyéb, a fej régióját érintő középvonali fejlődési rendellenesség részeként találkozhatunk. Az utóbbi 30 év intenzív állatmodell-kísérletei alapján egyre több ismeret áll rendelkezésre az adenohypophysis embrionális fejlődését szabályozó mechanizmusokról. Egyértelművé vált, hogy a hypophysis fejlődését számos transzkripciós faktor szabályozza, amelyek az embriogenezis jól meghatározott szakaszaiban, sejtspecifikus módon expresszálódnak. Az elmúlt 5 év kutatási eredményeiből az is nyilvánvaló lett, hogy a szabályozásban központi szerepet játszó hypophysistranszkripciós faktorokat kódoló gének csírasejtes mutációin kívül a sejtspecifikus jelátviteli utakban szerepet játszó egyéb molekulák (például fibroblastnövekedési faktorok, az immunglobulin-glikoprotein szupercsaládba tartozó molekulák) genetikai eltérései is okozhatnak veleszületett hypophysiselégtelenséget. Az agyalapi mirigy organogenezisének korai szakaszát szabályozó molekulák genetikai hibái gyakran extrahypophysealis fejlődési zavarral is járnak, míg az adenohypophysis fejlődésében később megjelenő transzkripciós faktorok mutációi általában nem társulnak egyéb központi idegrendszeri fejlődési rendellenességgel.

\section{Az adenohypophysis embrionális fejlődését szabályozó mechanizmusok}

A humán adenohypophysis fejlődése a 3. embrionális héten kezdődik az oralis ectoderma felső-hátsó sejtjeinek proliferációjával. Az organogenezis három szakaszát sejtspecifikus módon, meghatározott időbeli expressziót mutató transzkripciós faktorok és egyéb jelátviteli molekulák kaszkádja szabályozza.

Elsőként - az embrionális fejlődés 3-4. hetében - az oralis ectoderma egy jól körülírt szakasza megvastagodik (hypophysisplacod), majd a felette lévő diencephalon neuroectodermájából származó szignalizációs molekulák hatására (bone morphogenic protein-4 [BMP4] a fibroblastnövekedési faktor-8 és -10 [FGF8 és FGF10]) a középagyi struktúrák felé boltosul. A fejlődésnek ezt a korai szakaszát a legkorábban expresszálódó molekulákról elnevezett jelpályák szabályozzák. Az oralis ectodermában megjelenő sonic hedgehog (Shb) protein, a környező mesenchyma sejtjei által expresszált bone morphogenic protein $2(B m p 2)$ és chordin, valamint a fejlődő Rathke-tasak által szintetizált $B m p 2$, winglesstype mouse mammary tumor virus integration site 4 (Wnt4) molekulákat azonosították a fejlődést irányító jelpályák kiindulópontjaiként (SHH, BMP, FGF és WNT jelátviteli utak). Ebben a stádiumban a hypophysisőssejtek telepét egy HESXI (homeobox expressed in ES cells 1), illetve SOX2-pozitív (SRY ([Sex-Determining Region Y]-Box 2) sejtcsoport alkotja [3].

A későbbiekben a középagy felé kiboltusuló hypophysisplacodból a Rathke-tasak fejlődik, amelyet a lefüződéséig egy kocsányszerü képlet köt össze az oralis ectodermával, majd ez az összeköttetés később spontán felszívódik. Ezzel párhuzamosan a neuralis ectoderma kiboltosulásából a hypophysis hátsó lebenye fejlődik. Az érett Rathke-tasak és a hormontermelést még nem végző progenitor sejtek kialakulásában kiemelkedő fontosságú az FGF jelátviteli útvonal, valamint a paired-like homeodomain 2 es 1 (Pitx2 és Pitxl) LIM homeobox protein 3 és 4 ( $L h x 3$ és $L h x 4$ ) transzkripciós faktorok.

A fejlődés harmadik szakaszában egyes sejtvonal-specifikus transzkripciós faktorok hatására a hypophysis progenitor sejtekből specifikus hormontermelő sejtek differenciálódnak. A legkorábban a TSH, LH, FSH közös -alegysége detektálható a hypophysis rostralis csúcsánál, melyet a ventralis tireotrop sejtek TSH $\beta$-alegysége, illetve a melanokortikotrop sejteket jellemző proopiomelanokortin követ. Végül a szomatolaktotrop, a dorsalis tireotrop és a gonadotrop sejteknek megfelelő növekedési hormon, prolaktin, TSH $\beta$-, LH $\beta$ - és FSH $\beta$-alegység mutatható ki [4].

$\mathrm{Az}$ adenohypophysis fejlődésében részt vevő transzkripciós faktorokat kódoló gének mutációi típusosan veleszületett hypopituitarismust, de más szindrómákat is okozhatnak. A fejlődés korai szakaszában megjelenő faktorok genetikai eltérései a kombinált hypophysiselégtelenség mellett egyéb központi idegrendszeri fejlődési zavar társulásával is járhatnak. Az organogenezis későbbi szakaszát szabályozó transzkripciós faktorok génhibái általában kombinált, ritkábban izolált hypophysishormonhiányt okoznak.

A hypophysis fejlődését szabályozó legismertebb transzkripciós faktorok szerepét, a defektusuk által okozott kórképeket és öröklődésmenetüket az 1 . táblázatban foglaljuk össze [5-14]. 


\section{Veleszületett hypophysiselégtelenséggel társuló extrahypophysealis szindrómák}

$\mathrm{Az}$ adenohypophysis fejlődésének korai szakaszában expresszálódó gének defektusai változatos klinikai megjelenéssel járnak. Ezen összetett fejlődési rendellenességek közös vonása, hogy képalkotó vizsgálatokkal (pl. MRIvizsgálattal) a központi idegrendszer más szerveinek fejlődési rendellenességei mellett a hypophysismorfológia is kórosnak ábrázolódik. A klinikai képet a társuló idegrendszeri problémák és a hypophysishormon-hiány együttesen határozzák meg [15].

\section{Hypophysiselégtelenség és középvonali fejlödési rendellenességek}

A középvonali struktúrák fejlődési rendellenességei széles klinikai spektrumot foglalnak magukban. KoponyaMRI-vel azonosítható jellegzetes triász okozza a bypophysisnyél megszakadásával járó szindrómát (pituitary stalk interruption syndrome, PSIS): vékony vagy hiányzó hypophysisnyél, ectopiás vagy hiányzó neurohypophysis és kicsiny vagy hiányzó adenohypophysis. Az érintett újszülötteknél elhúzódó sárgaság, hypoglykaemia, cryptorchismus, micropenis lehet jelen, míg a fejlődés későb-

1. táblázat |Az adenohypophysis fejlődését szabályozó, kombinált hypophysishormon-hiányt okozó legfontosabb transzkripciós faktorok

\begin{tabular}{|c|c|c|c|c|c|}
\hline $\begin{array}{l}\text { Transzkripciós } \\
\text { faktor }\end{array}$ & Szerepe a hypophysisfejlődésben & Öröklődés & Extrahypophysealis tünetek & Hormonhiány & Koponya-MRI-eltérés \\
\hline \multicolumn{6}{|c|}{ Az adenohypophysis fejlődésének korai szakaszában expresszálódó transzkripciós faktorok } \\
\hline SOX2 & $\begin{array}{l}\text { * a fejlődő Rathke-tasak őssejtjeinek } \\
\text { proliferációját segíti elő [8] }\end{array}$ & $\mathrm{AD} \dagger$ & $\begin{array}{l}\text { septoopticus dysplasia } \\
\text { microphthalmia } \\
\text { mentális retardáció }\end{array}$ & $\begin{array}{l}\text { változatos } \\
\text { CPHD HH }\end{array}$ & adenohypophysishypoplasia \\
\hline OTX2 & $\begin{array}{l}\text { * a hypothalamus és a neuro- } \\
\text { hypophysis fejlődését szabályozza } \\
\text { [9] }\end{array}$ & $\mathrm{AD} \dagger$ & $\begin{array}{l}\text { anophthalmia/micro- } \\
\text { phthalmia }\end{array}$ & $\begin{array}{l}\text { változatos } \\
\text { CPHD } \\
\text { (izolált GH) }\end{array}$ & $\begin{array}{l}\text { adenohypophysishypoplasia } \\
\text { ectopiás neurohypophysis }\end{array}$ \\
\hline PITX2 & $\begin{array}{l}\text { * a Rathke-tasak korai fejlődését } \\
\text { szabályozza } \\
\text { * a szervezet jobb-bal oldaliságának } \\
\text { kialakulását mediálja }[10,11]\end{array}$ & $\mathrm{AD} / \mathrm{AR}$ & $\begin{array}{l}\text { Axenfeld-Rieger-szindró- } \\
\text { ma }\end{array}$ & $\begin{array}{l}\text { CPHD } \\
\text { vitatott }\end{array}$ & $\begin{array}{l}\text { szemüreg elülső kompart- } \\
\text { mentjének anomáliái }\end{array}$ \\
\hline LHX3 & $\begin{array}{l}\text { * a Rathke-tasakban a TSH } \beta, \mathrm{LH} \beta \text {, } \\
\text { FSH } \beta \text { hormonok szintézisét segíti } \\
\text { elő } \\
\text { * gerincvelooi motoneuronok } \\
\text { fejlődését mediálja [12] }\end{array}$ & $\mathrm{AR}$ & $\begin{array}{l}\text { szenzoros hallásvesztés } \\
\text { rövid nyaki gerinc } \\
\text { nyaki rigiditás }\end{array}$ & $\begin{array}{l}\text { változatos } \\
\text { CPHD }\end{array}$ & $\begin{array}{l}\text { adenohypophysishypo-, } \\
\text { illetve -hyperplasia elófordul- } \\
\text { hat }\end{array}$ \\
\hline LHX4 & $\begin{array}{l}\text { * a Rathke-tasakban a TSH } \beta, \mathrm{LH} \beta \text {, } \\
\text { FSH } \beta \text { hormonok szintézisét segíti } \\
\text { elő } \\
\text { * az adenohypophysis differenciálat- } \\
\text { lan progenitor sejtjeinek proliferá- } \\
\text { cióját segíti elő [13] } \\
\text { * a tüdőfejlődésben vesz részt }\end{array}$ & $\mathrm{AD} \dagger(\mathrm{AR})$ & - & $\begin{array}{l}\text { változatos } \\
\text { CPHD }\end{array}$ & $\begin{array}{l}\text { adenohypophysishypoplasia } \\
\text { ectopiás neurohypophysis } \\
\text { corpus callosum hypoplasia }\end{array}$ \\
\hline HESXl & $\begin{array}{l}\text { * az adenohypophysis progenitor } \\
\text { sejtjeinek proliferációját segíti elő } \\
\text { * a fejlődő előagyi struktúrák } \\
\text { kialakulását segíti elő }[14]\end{array}$ & $\mathrm{AD} \dagger(\mathrm{AR})$ & septoopticus dysplasia & $\begin{array}{l}\text { változatos } \\
\text { CPHD/ } \\
\text { izolált GH }\end{array}$ & $\begin{array}{l}\text { adenohypophysishypoplasia } \\
\text { ectopiás neurohypophysis } \\
\text { corpus callosum hypoplasia } \\
\text { nervus opticus anomalia }\end{array}$ \\
\hline ARNT2 & $\begin{array}{l}\text { az adenohypophysis, a szem és a } \\
\text { vesefejlődést mediálja [5] }\end{array}$ & $\mathrm{AR}$ & $\begin{array}{l}\text { látászavar } \\
\text { vese- és húgyúti fejlődési } \\
\text { zavar }\end{array}$ & $\begin{array}{l}\text { változatos } \\
\text { CPHD } \\
\text { centralis D. I. }\end{array}$ & $\begin{array}{l}\text { adenohypophysishypoplasia } \\
\text { ectopiás neurohypophysis } \\
\text { corpus callosum hypoplasia }\end{array}$ \\
\hline \multicolumn{6}{|c|}{ Az adenohypophysis fejlődésének késői szakaszában expresszálódó transzkripciós faktorok } \\
\hline PROPl & $\begin{array}{l}\text { * a POUlFl-et aktiválja } \\
\text { * gonadotrop sejtvonal differenciáló- } \\
\text { dása [6] }\end{array}$ & AR & - & $\begin{array}{l}\text { változatos } \\
\text { CPHD }\end{array}$ & \multirow{2}{*}{$\begin{array}{l}\text { adenohypophysishypo-, } \\
\text { illetve -hyperplasia előfordul- } \\
\text { hat }\end{array}$} \\
\hline POUlFl & $\begin{array}{l}\text { * szomato-, lakto-, tireotrop } \\
\text { sejtvonal differenciálódása [7] }\end{array}$ & $\mathrm{AR}(\mathrm{AD})$ & - & $\begin{array}{l}\text { GH, PRL, } \\
\text { TSH }\end{array}$ & \\
\hline
\end{tabular}

†A családon belüli inkomplett penetrancia gyakori.

$\mathrm{AD}=$ autoszomális domináns; $\mathrm{AR}=$ autoszomális recesszív; $\mathrm{CPHD}=$ kombinált hypophysiselégtelenség; $\mathrm{D}$. $\mathrm{I}$. = diabetes insipidus; $\mathrm{HH}=$ hypogonadotrop hypogonadismus 
bi szakaszában növekedési zavar, alacsony vérnyomás és meglassult értelmi fejlődés hívhatja fel a figyelmet az öszszetett fejlődési rendellenességre. Septoopticus dysplasiában (SOD) agyi fejlődési zavarok (septumagenesia, corpus callosum agenesia) és a nervus opticus hypoplasiája társul kombinált hypophysiselégtelenséggel. Holoprosencephaliában (HPE) az embrionális fejlődés 18. és 28. napja közötti időszakban nem történik meg a prosencephalon kettéhasadása és ezáltal a két agyfélteke kialakulása. Mindez komplex agyi és arcmalformációhoz, mentális retardációhoz vezet, az érintett magzatok általában nem életképesek. Ezen előagyi fejlődési rendellenességeket az adenohypophysis fejlődésének korai szakaszában expresszálódó transzkripciós faktorokat kódoló gének mutációi okozhatják (sonic hedgehog [SHH], zinc finger of the cerebellum [ZIC] protein family member 2 [ZIC2], LHX4, HESX1, fibroblast growth factor receptor 1 [FGFR 1], FGF8, prokineticin-2 [PROK2], prokineticin receptor 2 [PROKR2]). Az utóbbi évek kutatási eredményei hangsúlyozzák, hogy az érinett transzkripciós faktorok genetikai hibái sokszor nem körülhatároltan idézik elő a felsorolt szindrómákat, hanem egymásba érő klinikai tünetekkel járó, változatos kórképeket okoznak, amelyekben változó súlyosságú előagyi fejlődési rendellenességek alakulhatnak ki [16].

\section{Hypophysiselégtelenség és szemfejlödési rendellenességek}

A jellemzően a szem elülső szegmensét érintő fejlődési zavarok és a congenitalis hypopituitarismus társulásának hátterében a korai hypophysistranszkripciós faktorok közül az OTX2- és a SOX2-gén defektusai azonosíthatók. A PITX2-gén-mutációk ún. Axenfeld-Rieger-szindrómát okozhatnak a szemüreg elülső kompartmentjének fejlődési rendellenességeivel és egyéb szisztémás malformációkkal (pl. craniofacialis dysmorphia, fog- és umbilicalis anomáliák). A kórkép hypophysiselégtelenséggel való társulása vitatott. $\mathrm{Az} A R N T 2$ genetikai hibáit egy ritka, komplex fejlődési rendellenesség (látászavar, postnatalis microcephalia, veleszületett hypopituitarismus, centralis diabetes insipidus, vesefejlődési zavarok) kóroki tényezőiként azonosították [5].

\section{A kombinált hormonhiánnyal járó hypophysiselégtelenség leggyakoribb formái}

$\mathrm{Az}$ adenohypophysis fejlődésének késői szakaszában expresszálódó transzkripciós faktorok defektusai típusosan összetett, ritkábban izolált hypophysishormon-hiánynyal járó kórképeket okoznak. Ezekben az esetekben általában a sella- vagy koponya-MRI-vizsgálat megtartott hypophysismorfológiát mutat, míg egyéb központi idegrendszeri strukturális eltérések nem jellemzőek. A klinikai képet a hypophysishormon-hiány(ok) határozzák meg.

\section{A PROPl-gén-mutáció által okozott kombinált bypophysiselégtelenség}

Az egyéb fejlődési rendellenességgel nem társuló, veleszületett kombinált hypophysiselégtelenség (combined pituitary hormone deficiency, CPHD) hátterében a legtöbbször a Prophet of Pitl (PROPI-) gén autoszomális recesszív módon öröklődő mutációit azonosították. Saját vizsgálatunkban 35, gyermekkorban manifesztálódó CPHD-s beteg PROPI-gén-szekvenciaanalízisét elvégezve, 15 beteg esetében (43\%) igazolódott PROPlgén-mutáció [17, 18].

$\mathrm{Az}$ adenohypophysis organogenezisét irányító transzkripciós faktorok jellegzetes kaszkádjában a PROPl transzkripciós fehérje expressziója a HESXI expressziójának csökkenését (transzkripciós represszor hatás), majd néhány nappal később a pituitary-specific positive transcription factor 1 (Pitl, vagy más néven a POU domain, class 1, transcription factor 1 [POUlFl]) expresszióját okozza (transzkripciós aktivátor funkció) [19].

A PROPl felelős a gonadotrop sejtek differenciálódásáért, illetve a POUlFl-fehérje aktiválásával a szomatotrop, laktotrop és tireotrop sejtek specifikációjáért. A közelmúltban transzgenikus egérmodellen bizonyították, hogy az agyalapi mirigy elülső és intermedier lebenyében a hormontermelő sejtek mindegyike keresztülmegy egy stádiumon, amikor a PROPl expressziója jelen van - ennek alapján egy közös progenitor sejtre következtethetünk [6].

A betegségokozó PROPl-gén-mutációt hordozó betegek longitudinális vizsgálatával igazolták, hogy a többszörös hypophysishormon-hiány progresszíven alakul ki. $\mathrm{Az}$ érintett betegek endokrinológiai vizsgálata általában gyermekkorban észlelt GH-szekréciós zavar által okozott növekedési elmaradás kivizsgálása miatt kezdődik meg. A mérsékelt növekedési elmaradást okozó GH-hiány mellett a betegekben ritkán már születéskor, de gyakrabban az életkor előrehaladtával TSH-hiány, illetve változatos klinikai képben manifesztálódó hypogonadotrop hypogonadismus jelentkezik. Ez utóbbira születéskor micropenis és cryptorchismus, később a serdülés zavara vagy ritkán spontán pubertás után észlelhető infertilitás utalhat. Mindez arra utal, hogy a PROPl-génmutációt hordozó GH-hiányos betegek rendszeres endokrinológiai ellenőrzése elengedhetetlenül fontos a társuló hormonhiányok időben történő felismeréséhez [20]. Kiemelkedő jelentősége van a hazai populáció szempontjából is, hogy a leggyakoribb, c.150delA PROPlgén-variáns esetén alapító hatást („founder effect”) igazoltak, mely szerint ez a genetikai eltérés a legnagyobb valószínúséggel a közép-európai régióból származik [21].

A sellarégió MRI-vizsgálata a legtöbbször normális viszonyokat, illetve gyakran az agyalapi mirigy elülső lebenyének hypoplasiáját mutatja, ritkán azonban adenohypophysishyperplasiát is leírtak. A veleszületett 
CPHD esetén eddig csak a PROPl-defektust hordozó egyéneknél írták le a hypophysisméret dinamikus változását („vaxing and waning”), melynek során a hypophysis elülső lebenyének mérete változik [22]. A betegekben a neurohypophysis minden esetben normális morfológiájú és elhelyezkedésű.

\section{A POU1F1-gén-mutáció által okozott kombinált hypophysiselégtelenség}

A Pitl (POUlFl) transzkripciós fehérje expressziója az adenohypophysis fejlődésének legutolsó szakaszában kezdődik, a PROPl aktivációs hatására. A POUIFI-fehérje szükséges a szomatotrop, laktotrop sejtek, valamint a legtöbb tireotrop sejt differenciációjához. A Pitl-expresszió postnatalisan, sôt felnőttkorban is kimutatható ezekben a sejttípusokban.

A POU1F1-gén-mutációk szinte kivétel nélkül autoszomális recesszív módon öröklődnek. Leghamarabb a GH-hiány tünetei jelentkeznek, a TSH- és PRL-hiány később, a gyerekkor során manifesztálódik. MRI-vizsgálattal normális vagy hypoplasiás adenohypophysis ábrázolódik, a neurohypophysis és más központi idegrendszeri struktúrák épek [7].

\section{Az izolált hormonhiánnyal járó hypophysiselégtelenség leggyakoribb formái}

\section{Congenitalis izolált ACTH-hiány}

Az újszülöttkori izolált ACTH-hiány hátterében a leggyakrabban (az esetek kb. 2/3-ában) a T-Pit (TBX19, T-box transcription factor 19) transzkripciós fehérje mutációja igazolható. Ezekben az esetekben a kórkép autoszomális recesszív öröklődést mutat. A T-Pit alapvető funkciója a melanokortikotrop és a kortikotrop sejtvonal érésének elősegítése, a proopiomelanokortin (POMC) és a prohormonkonvertáz-2 (PC2) expressziójának indukciója. A TBX19 defektusa következtében mind a POMC szintézise, mind a POMC-ból az ACTH kihasítása elmarad. Congenitalis izolált ACTH-hiány esetén a magzati mellékvese androgéntermelődése csökkent. Az alacsony fetalis androgénkínálat miatt a placentáris androgénaromatizáció alacsony ösztriolszintet okoz az anyában. Ennek diagnosztikus jelentősége kiemelkedő a második trimeszter során végzett triple-screen (AFP, beta-hCG, ösztriol) kiértékelésekor [23]. Az érintett újszülöttekben súlyos hypoglykaemia és elhúzódó, cholestaticus eredetû sárgaság alakul ki $[24,25]$. A korai, pontos diagnózis életmentő lehet, mivel a megfelelő hidrokortizonpótlás késlekedése életveszélyes hypadreniához vezethet.

\section{Congenitalis hypogonadotrop bypogonadismus}

A GnRH-t termelő neuronok migrációját, a gonadotrop sejtek differenciálódását számos protein, transzkripciós faktor szabályozza. A fehérjéket kódoló génekben bekövetkező genetikai károsodás hatására izolált hypogonadotrop hypogonadismus $(\mathrm{IHH})$ alakul ki. Az érintett betegek kb. 60\%-ában Kallmann-szindróma igazolható, melyben az IHH anosmiával-hyposmiával társul. A kórképet a GnRH-neuronok orrplacod felőli migrációjának zavara okozza, melynek hátterében számos gén mutációját kimutatták. Normosmiás IHH-betegekben az összes géndefektus ismertetése meghaladja a jelen összefoglalónk kereteit, ezért csak néhány speciális szituáció megemlítésére szorítkozunk, amikor az egyéb társuló klinikai tünetek segíthetnek a kórképet okozó gének kiválasztásában. IHH mellett kimutatott congenitalis adrenalis hypoplasia esetén a gonadotrop sejtvonal, illetve a mellékvesekéreg fejlődésében részt vevo „dosage sensitive sex reversal, adrenal hypoplasia congenita on the $\mathrm{X}$ chromosome gene 1 " (DAXI vagy NROBI) transzkripciós faktor génmutációja várható, ami X-hez kötött recesszív öröklódést mutat. Nyúlajak, a fogak diszgenezise, középvonali fejlődési rendellenességek a fibroblastnövekedési faktor hiányára (FGF8) vagy a fibroblastnövekedési faktor receptorának mutációjára (FGFRl) hívhatják fel a figyelmet. IHH és hallászavar esetén a ,chromodomainhelicase-DNA-binding protein 7" (CHD7) gén mutációja merülhet fel. Az adenohypophysisben és a gonádokban is expresszálódó szteroidogenetikus faktor-1 (SF1 vagy $\mathrm{NR} 5 \mathrm{Al}$ ) génhibái esetén a változatos klinikai kép egyik megjelenési formája lehet, amikor a veleszületett centralis hypogonadismus primer mellékvesekéreg-elégtelenséggel együtt jelentkezik [26].

\section{Congenitalis izolalt centralis hypothyreosis}

A veleszületett centralis hypothyreosis a legtöbbször nem izoláltan, hanem egyéb hypophysishormon-hiányhoz társulva jelentkezik. A ritka izolált centralis hypothyreosis eseteiben a legtöbbször az „immunoglobulin superfamily member l" (IGSFl-) proteint kódoló gén mutációit azonosították. A tireotrop sejtekben IGSFl hatására fokozódik a TRH-receptor expressziója, míg hiányában centralis hypothyreosis alakul ki. A kórképhez általában FSH-elválasztási zavar is társul, mivel a gonadotrop sejtekben az IGSFI hiánya összességében megnövekedett FSH $\beta$-szintézishez vezet. Ennek következtében az érintett betegekben serdülő-, illetve fiatal felnőtt korban a Sertoli-sejtek fokozott stimulációja és proliferációja miatt kétoldali, szimmetrikus heremegnagyobbodás alakul ki. Szintén izolált centralis hypothyreosist okozhatnak az „F-box-like/WD repeat-containing protein” (TBLIX-) gén mutációi, aminek következtében a T3-hormon szintézise csökken. A génmutációk mindkét esetben X-hez kötött módon öröklődnek [27]. 


\section{Congenitalis izolált GH-biány}

Azokban az újszülött-, illetve kisgyermekkorban igazolt GH-hiányos betegekben, akiknél a GH-hiány felnőttkorban is kimutatható, az életkor előrehaladtával egyéb hypophysishormon-hiány társulása is észlelhetó, vagyis valódi izolált GH-hiány csak a betegek kis részében mutatkozik. A valódi izolált GH-hiányos betegekben pl. olyan POU1Fl-gén-mutációt azonosítottak, amely csak a GH-elválasztást gátolja, a GH génjének specifikus promoter régiójához kapcsolódva [28].

\section{A hypophysistranszkripciós faktorok szerepe a hypophysisdaganatok patológiai kórismézésében és prognózisában}

A hypophysistranszkripciós faktorok klinikai jelentőségét jelentősen megnövelte a WHO által 2017 őszén kiadott új ajánlás, melyben a hypophysisadenomák patológiai besorolását döntően a tumorsejtek fejlődéstani eredetére alapozzák. A WHO legújabb javaslata alapján a hypophysisadenomákat a jövőben nemcsak hormontermelésük jellege alapján osztályozzák, hanem a tumorokat alkotó sejtek fejlődéstani eredetének megfelelően is, ami a daganatok új nevezéktanában is megjelenik (szomatotrop, laktotrop, tireotrop, kortikotrop, gonadotrop, nullsejtes adenomák, továbbá plurihormonális adenomák). A patológiai diagnózisalkotásban a tumorsejtek transzkripciósfaktor-mintázata meghatározó lehet olyan esetekben, amikor alacsonyan differenciált tumorok biológiai viselkedését kell megjósolni. Ezért az új ajánlás a hagyományos immunhisztokémiai vizsgálatok mellett a hypophy- sistranszkripciós faktorok és egyéb sejtspecifikus fehérjék expressziójának vizsgálatát is javasolja [29]. Az 1. ábrán bemutatjuk az adenohypophysis sejtjeinek differenciálódását szabályozó legfontosabb faktorokat. Az ábrán külön megjelöltük azokat a faktorokat, amelyek vizsgálata javasolt a hypophysisadenomák patológiai vizsgálatai során.

\section{Következtetés}

Közleményünkben áttekintettük azokat a legfontosabb genetikai eltéréseket, amelyek extrahypophysealis szindrómához társulva veleszületett hypophysiselégtelenséget okoznak. Bemutattuk a transzkripciós faktorok mutációi által okozott jellegzetes, többszörös vagy izolált hypophysishormon-hiánnyal, valamint extrahypophysealis manifesztációkkal is járó klinikai szindrómákat. Végül a WHO legújabb ajánlásának megfelelően összefoglaltuk a hypophysistranszkripciós faktorok szerepét a hypophysisdaganatok szövettani osztályozásában.

Anyagi támogatás: A szerzők anyagi támogatásban nem részesültek.

Szerzôi munkamegosztás: T. J.: A kézirat koncepciójának megalkotása, szövegezése. B. R., G. P., H. Z.: A kézirat koncepciójának megalkotása, a szövegezés javítása. A cikk végleges változatát valamennyi szerző elolvasta és jóváhagyta.

Érdekeltségek: A szerzőknek nincsenek érdekeltségeik.

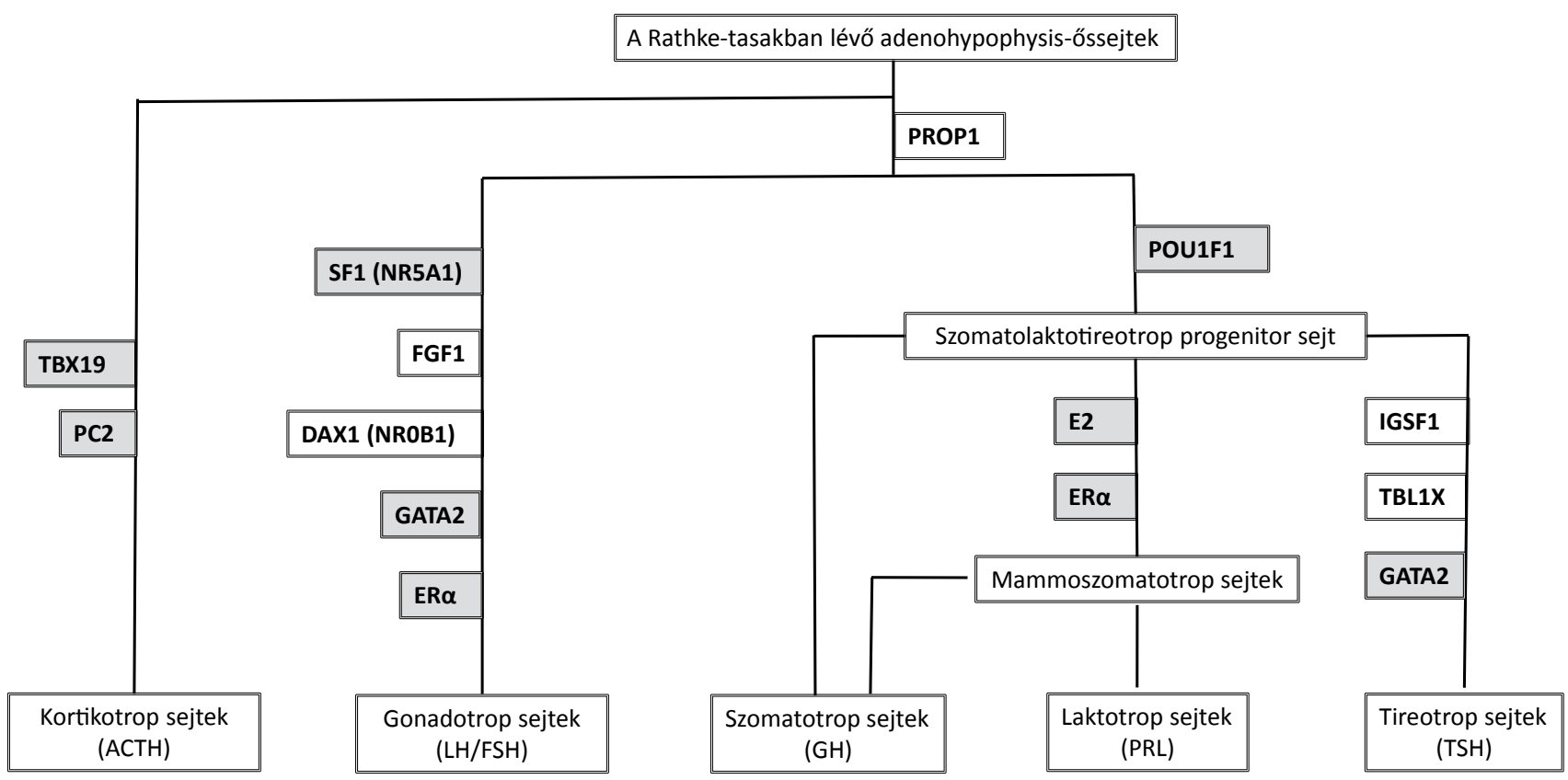

1. ábra $\quad$ Az adenohypophysis hormontermelő sejtjeinek differenciálódását szabályozó legfontosabb faktorok.

A szürke háttérrel megadott faktorok vizsgálata támpontot nyújt a hypophysistumorok patológiai kórismézésében 


\section{Köszönetnyilvánítás}

A szerzők ezúton fejezik ki hálájukat és tiszteletüket Rácz Károly professzor úr iránt, aki lehetővé tette a Semmelweis Egyetem II. Belgyógyászati Klinikáján az általa alapított Endokrinológiai Molekuláris Biológiai Laboratóriumban a veleszületett hypophysiselégtelenség genetikai vizsgálatát.

A szerzők köszönetüket fejezik ki a Laboratórium munkatársainak és jelenlegi vezetőjének, dr. Patócs Attilának a veleszületett hypophysiselégtelenség genetikai kivizsgálásához nyújtott együttmúködésért.

\section{Irodalom}

[1] Baş F, Uyguner ZO, Darendeliler F, et al. Molecular analysis of PROP1, POU1F1, LHX3, and HESX1 in Turkish patients with combined pituitary hormone deficiency: a multicenter study. Endocrine 2015; 49: 479-491.

[2] Dattani MT. Novel insights into the aetiology and pathogenesis of hypopituitarism. Horm Res. 2004; 62(Suppl 3): 1-13.

[3] Fauquier T, Rizzoti K, Dattani M, et al. SOX2-expressing progenitor cells generate all of the major cell types in the adult mouse pituitary gland. Proc Natl Acad Sci USA 2008; 105: 2907-2912.

[4] Bancalari RE, Gregory LC, McCabe MJ, et al. Pituitary gland development: an update. Endocr Dev. 2012; 23: 1-15.

[5] Webb EA, AlMutair A, Kelberman D, et al. ARNT2 mutation causes hypopituitarism, post-natal microcephaly, visual and renal anomalies. Brain 2013; 136: 3096-3105

[6] Davis SW, Keisler JL, Pérez-Millán MI, et al. All hormone-producing cell types of the pituitary intermediate and anterior lobes derive from Propl-expressing progenitors. Endocrinology 2016; 157: 1385-1396.

[7] Turton JP, Reynaud R, Mehta A, et al. Novel mutations within the POUIFI gene associated with variable combined pituitary hormone deficiency. J Clin Endocrinol Metab. 2005; 90: 47624770 .

[8] Goldsmith S, Lovell-Badge R, Rizzoti K. SOX2 is sequentially required for progenitor proliferation and lineage specification in the developing pituitary. Development 2016; 143: 2376-2388.

[9] Mortensen AH, Schade V, Lamonerie T, et al. Deletion of OTX2 in neural ectoderm delays anterior pituitary development. Hum Mol Genet. 2015; 24: 939-953.

[10] Seifi M, Walter MA. Axenfeld-Rieger syndrome. Clin Genet. 2017 Oct 3; doi: $10.1111 /$ cge.13148. [Epub ahead of print]

[11] Shiratori H, Yashiro K, Shen MM, et al. Conserved regulation and role of Pitx2 in situs-specific morphogenesis of visceral organs. Development 2006; 133: 3015-3025.

[12] Park S, Mullen RD, Rhodes SJ. Cell-specific actions of a human $L H X 3$ gene enhancer during pituitary and spinal cord development. Mol Endocrinol. 2013; 27: 2013-2027.

[13] Gergics P, Brinkmeier ML, Camper SA. Lhx4 deficiency: increased cyclin-dependent kinase inhibitor expression and pituitary hypoplasia. Mol Endocrinol. 2015; 29: 597-612.

[14] Fang Q, Benedetti AF, Ma Q, et al. HESX1 mutations in patients with congenital hypopituitarism: variable phenotypes with the same genotype. Clin Endocrinol (Oxf). 2016; 85: 408-414.

[15] Castinetti F, Reynaud R, Quentien MH, et al. Combined pituitary hormone deficiency: current and future status. J Endocrinol Invest. $2015 ; 38: 1-12$.
[16] Raivio T, Avbelj M, McCabe MJ, et al. Genetic overlap in Kallmann syndrome, combined pituitary hormone deficiency, and septo-optic dysplasia. J Clin Endocrinol Metab. 2012; 97: E694-E699.

[17] Halász Z, Tóke J, Patócs A, et al. High prevalence of PROPI gene mutations in Hungarian patients with childhood-onset combined anterior pituitary hormone deficiency. Endocrine 2006; 30: 255-260.

[18] Halász Z. Genetic background of inherited multiple pituitary hormone deficiency. Mutations of PROPI gene in Hungary. [A veleszületett többszörös hypophysishormon-hiány genetikai okai. A PROPl génmutációk vizsgálata hazai betegekben.] Orv Hetil. 2011; 152: 221-232. [Hungarian]

[19] Olson LE, Dasen JS, Ju BG, et al. Paired-like repression/activation in pituitary development. Recent Prog Horm Res. 2003; 58: 249-261.

[20] Böttner A, Keller E, Kratzsch J, et al. PROPI mutations cause progressive deterioration of anterior pituitary function including adrenal insufficiency: a longitudinal analysis. J Clin Endocrinol Metab. 2004; 89: 5256-5265.

[21] Dusatkova P, Pfäffle R, Brown MR, et al. Genesis of two most prevalent PROPI gene variants causing combined pituitary hormone deficiency in 21 populations. Eur J Hum Genet. 2016; 24 : 415-420.

[22] Obermannova B, Pfaeffle R, Zygmunt-Gorska A, et al. Mutations and pituitary morphology in a series of 82 patients with PROPI gene defects. Horm Res Paediatr. 2011; 76: 348-354.

[23] Weintrob N, Drouin J, Vallette-Kasic S, et al. Low estriol levels in the maternal triple-marker screen as a predictor of isolated adrenocorticotropic hormone deficiency caused by a new mutation in the TPIT gene. Pediatrics 2006; 117: e322-e327.

[24] Alsaleem M, Saadeh L, Misra A, et al. Neonatal isolated ACTH deficiency (IAD): a potentially life-threatening but treatable cause of neonatal cholestasis. BMJ Case Rep. 2016; doi: 10.1136/bcr-2016-215032.

[25] Couture C, Saveanu A, Barlier A, et al. Phenotypic homogeneity and genotypic variability in a large series of congenital isolated ACTH-deficiency patients with TPIT gene mutations. J Clin Endocrinol Metab. 2012; 97: E486-E495.

[26] Valdes-Socin H, Rubio Almanza M, Tomé Fernández-Ladreda $M$, et al. Reproduction, smell, and neurodevelopmental disorders: genetic defects in different hypogonadotropic hypogonadal syndromes. Front Endocrinol. (Lausanne) 2014; 5: 109.

[27] Persani L, Bonomi M. The multiple genetic causes of central hypothyroidism. Best Pract Res Clin Endocrinol Metab. 2017; 31 : 255-263.

[28] Giordano M. Genetic causes of isolated and combined pituitary hormone deficiency. Best Pract Res Clin Endocrinol Metab. 2016; 30: 679-691.

[29] Mete O, Lopes MB. Overview of the 2017 WHO Classification of Pituitary Tumors. Endocr Pathol. 2017; 28: 228-243.

(Tőke Judit dr.,

Budapest, Szentkirályi u. 46., 1088 e-mail: toke.judit@med.semmelweis-univ.hu) 